\title{
The influence of cyberization on folk religion: A case study of Chinese online religious group
}

\author{
Yuhang Zhang ${ }^{1 *}$ \\ ${ }^{1}$ School of Sociology $\mathcal{E}$ Population Studies, Renmin University of China, China \\ * Corresponding author \\ E-mail address: 2018201290@ruc.edu.cn \\ DOI: https://doi.org/10.21107/sml.v4i2.11511
}

\begin{tabular}{|c|c|}
\hline Article Info & Abstract \\
\hline $\begin{array}{l}\text { Keywords: } \\
\text { Folk religion } \\
\text { Cyberization } \\
\text { China } \\
\text { Online religion } \\
\text { Religious group }\end{array}$ & $\begin{array}{l}\text { Religious cyberization is a new way of dissemination and development } \\
\text { of traditional offline religions. In the process of cyberization, all aspects of } \\
\text { religions are likely to be affected by the new Internet environment. Taking } \\
\text { a Chinese online religious group as Internet field, this article analyzes the } \\
\text { influence of cyberization on belief system, religious authority and religious } \\
\text { experience of folk religion, and makes a preliminary exploration of its causes } \\
\text { in combination with the characteristics of Internet and folk religion. This } \\
\text { study mainly adopted the method of participant observation, and conducted } \\
\text { online and offline interviews with participants when necessary. In addition, } \\
\text { the researcher also analyzed documents, audio and other files uploaded in } \\
\text { the online group. In the case discussed in this article, compared with officially } \\
\text { recognized religions in China, folk religion seems to be more adapted to the } \\
\text { opportunities and challenges brought by the new territory of the Internet } \\
\text { due to its unique diffuseness and inclusiveness. }\end{array}$ \\
\hline
\end{tabular}

Citation suggestion:

Zhang, Y. (2021). The influence of cyberization on folk religion: A case study of Chinese online religious group. Simulacra, 4(2), 157-168. https://doi.org/10.21107/sml.v4i2.11511

Received 17 August 2021; Received in revised form 26 September 2021; Accepted 2 October 2021; Published online 25 November 2021. 


\section{Introduction}

Cyberization is the process of forming a new cyberworld and transforming our current physical, social and mental worlds into novel cyber-combined ones (Ma, 2016). China's internet space has undergone tremendous changes in the past decade. The number of internet users has grown rapidly, and various social software and self-media platforms have mushroomed. With the cyberization of various social phenomena, the internet space has gradually been given sociality. At the same time, the internet is also reshaping people's real lives. As an important social phenomenon, religion has produced many new changes in the process of being gradually embedded in the internet space.

At present, there is no general agreement on the terminologies to classify and define all kinds of religious information and practices that exist in the internet space. The main terms include "internet religion", "digital religion", "online religion", "religion online" and so on. "Religion Online" and "Online Religion" are the classification methods of religions in the internet space proposed by Helland (Helland, 2000), which respectively refer to the unidirectional information dissemination of various types of religious information presented on the internet, and the religious mode that Individual believers and religious organizations can realize a twoway interaction on the internet. However, with the highly developed internet today, the boundary between these two types of religions has been very blurred, and it is difficult to find a religion that exists only in one of these forms in the internet space. The research object of this study is an online religious group that has both of these two modes. The belief of this group was developed from the offline Shamanism of northern China. The group contains not only religious information such as scriptures and doctrines published in the form of text, voice and so on, but also interactive activities such as religious ceremonies and discussion of religious issues. Based on the theme of this article, the researcher uses the term online religion to refer to the religious practices and discourses involved in this research.

The academic research on online religion began in the United States in the 1990s. The research in the early stage mostly focused on the description of online religious phenomena. The main topics include religious cyberization and its impact on religious transformation (O 'Leary, 1996), religious use of the internet (Cobb, 1998), and the basic development of online religion (Brasher, 2001). In the following two decades, scholars continued to deepen their research on online religion, from simply describing new phenomena and trends of the cyberization of religions, to exploring and explaining the changes and development of religions in the process of cyberization. These topics cover the main topics in traditional studies of sociology of religion, such as religious ritual, religious experience, identification, change of authority, community construction, while new topics, such as the classification of online religion and the mutual influence between religion and the internet, have also emerged.

Although the Western academic circles have systematically and comprehensively studied the cyberization of religions, they have neglected to pay attention to the phenomenon of the cyberization of religions in China in terms of case selection ( $\mathrm{Xu}$ \& Campbell, 2018). From a macro perspective, Campbell analyzed the characteristics of Chinese Online religions using Tibetan Buddhism, Islam, and Christianity as the starting point. These characteristics include: continuous flourishing growth, the coexistence and differentiation of religious online and online religions, the connection between religious issues and ethnicity, and 
that the attitudes and behaviors of believers on the Internet can reflect the identity of offline religions identification.

Compared with the West, Chinese academic circles pay less attention to issues related to cyberization of religion and the start is relatively late. The Center for American Studies at Fudan University held the first Symposium on Internet and Religion in China in 2004, which reflected the early research results of Chinese scholars on internet religion in China. The topics of these studies mainly include religious phenomena in the internet space, the influence of network technology on religion, and the basic situation of the operation of religious websites. After that, some studies also involved the rise of online religion in China (Tang, 2006; Shi \& Lu, 2016), the religious identification of online religious groups (Li, 2011), and the influence of online religion on believers (Tang, 2008; Zhang, 2018) and other topics. The abovementioned research mainly reveals the basic characteristics of online religions in China, such as young audience, decentralization, openness and virtuality. However, in recent years, more scholars have paid attention to the development trend and possible risks and problems of online religion (Xing, 2016; Wang, 2016; Li \&Gu, 2018; Zhang, Ma \& Zhang, 2018), and related exploration of governance countermeasures (Shi, 2016; Shi, 2018; Yang, 2018; Ma, 2020). The governance issues mentioned in these studies include the imperfection of relevant laws and regulations, the lack of entry barriers and exit mechanisms, and alienation phenomena such as superstition and cults.

In short, whether in the West or in China, research results on Chinese online religions still need to be improved. In recent years, Chinese scholars have conducted a lot of researches on the problems and governance of online religion from the perspectives of policy and public management, but they have rarely paid attention to issues such as religious experience and authority changes from the perspective of sociology. Moreover, researchers in the sociology of religion in both China and the West mainly analyze the characteristics of Chinese online religions from the perspective of institutional religions such as Christianity and Islam. Few studies have been conducted on the highly diffused folk religions with a broad following base in China. What changes have taken place in the process of cyberization of diffused folk religions? Compared with institutional religions, how are these changes different? These questions are the motivation of this article. Focusing on a China's folk religious group, this article analyzes its characteristics in combination with the particularity of the internet as a belief space, which will help enrich the existing researches on the cyberization of religion. Compared with the existing literature, the contribution of this article may be reflected in the following two aspects: one is to incorporate the particularity of folk religion into the analysis framework of religious cyberization, providing a new perspective; the other is taking a Chinese online folk religious group as the research object, which could enrich the research in this field.

\section{Method}

Participant observation and case study are commonly used in the study of online religion (Liang, 2020). The representative studies include Huang's study of the $\mathrm{O} 2 \mathrm{O}$ model of a Japanese religious group (Huang, 2018) and Tan's research on Buddhist virtual communities (Tan, 2019). This study mainly adopted the method of participant observation, and conducted online and offline interviews with participants when necessary. In addition, the researcher also analyzed documents, audio and other files uploaded in the group by the group owner. In the observation, the researcher first 
understood the general situation of the online group to form a preliminary understanding of the characteristics of the online religion in the group, and then selected specific interviewees to conduct in-depth interviews based on the analysis of the field notes.

The data collected in the early stage was mainly the observation of the weekly Dian Yuan activity in the group (Dian Yuan is a religious activity in which the shaman communicates with the spirit guides of followers in order to guide them to better lives and religious practices.). As an audience, researcher participated in the live stream of the Dian Yuan activity, focusing on the interaction between the group owner and ordinary group members, the dialogue between the group managers and other group members in the comments section, and some important events in the group. Besides, researcher also collected other information of online interactions among members of the group, such as discussing religious doctrines, exchanging religious experiences, and conducting religious rituals, and then analyzed the influence of the cyberization on this folk religion and the possible causes.

In order to ensure the objectivity of the study, the researcher would not make comments during the activities to maintain minimal interference with group members. After having an overall understanding of the religious belief in the group, the researcher selected some group members who were active and had characteristics in the group for interviews. The issues concerned in this study are generally not directly discussed in group chats and live stream activities, and the researcher could only obtain indirect information about these issues from religious activities and the discussion of group members. After that, the researcher conducted interviews to learn the followers' direct thoughts on these issues.

The research object of this study was an online religious group active on QQ:
Group C. QQ is one of the most important social media in China, with more than 600 million active users in the second quarter of 2020. There are a large number of online religious groups spontaneously established by believers or religious organizations on the platform. These groups provide believers with places to exchange religious-related issues and carry out religious activities beyond time and space. Group $\mathrm{C}$ has more than 800 members, including 1 group owner and 10 group managers. 39\% of these members are women, 53\% are men, and another $8 \%$ have not disclosed their gender. The owner of the group is a folk mage (shaman) from northeastern China, who often travels in various provinces in China to perform religious rites for believers. The age distribution of group members is relatively young, with more than $34 \%$ of the group members under 30 years old and $30 \%$ of them between 31-40 years old, which is the generation that has been greatly influenced by the internet.

The core part of this group's beliefs is Shamanism in northern China (an animist folk religion, hereinafter referred to as "Shamanism"), and it also incorporates mainstream Chinese religions such as Buddhism and Taoism, as well as other beliefs from the West such as occultism. In this group, the weekly routine Dian Yuan activity is the focus of this study. Each Saturday night, the group owner offers guidance to several members of the group for free. Anyone who has been in the group for more than a week can sign up for the activity. The specific form of Dian Yuan on the Internet is that the group owner communicates with the group members on online live stream. In the process, they may even talk about irrelevant topics with the participants and the audience, which is more casual than the offline Dian Yuan. The Dian Yuan activity of this group is a typical example of the transfer of offline religious 
activities to cyberspace, which makes it an important object of researcher's observation.

\section{Results and Discussion}

The development of internet technology has broken the limitations of time and space, and greatly reduced the cost of information transmission and acquisition, thus allowing users to obtain immense and more pluralistic information in a short period of time. In the process of cyberization of a certain offline religion, these factors actually bring several challenges. First, believers can easily learn information that was once monopolized by the religious authority of their religion. Second, believers can have more and more in-depth access to related information about other religions, which may pose a threat to their own religion. Third, if a certain belief or ritual is absent in the internet space, it will gradually be marginalized. At the same time, internet technology as an instrumental force has also become a new opportunity for the further dissemination and development of offline religions. The power of internet technology provides a push-pull mechanism for the rise of online religion (Tang, 2006). On the one hand, the challenges posed by the internet are driving offline religions to extend into the internet space. On the other hand, the use of the internet can play a role in traction and support for the development of offline religion. Based on the abovementioned challenges and opportunities that may be faced in the process of religious cyberization, the following mainly discusses their impacts on the belief system, religious authority, and religious experience.

\section{Belief system: The shift from single to composite}

In the process of embedding in the internet space, offline religious belief systems will inevitably change whether spontaneously or consciously. In general, the change from a single belief system to a composite belief system is one of the main characteristics of this transformation. The belief system of Group C is a composite belief system that takes Shamanism as the main body and integrates other beliefs such as Buddhism, Taoism, and occultism. The content discussed in the group, and the text and audio materials released by the group owner which represent the belief system of the group, does not only involve a single religion. As the religious leader of the group, the group owner's discourse system and religious practices have obvious characteristics of Shamanism.

Although this kind of folk belief has also borrowed some principles and elements of Taoism in its long-term development, its integration with Buddhism is not a longstanding practice, and its integration with Western beliefs such as occultism can be said to be purely a product of the Internet era. In order to allow believers to increase their understanding of this belief system, the group owner of Group C sometimes releases some audios explaining her religious principles in the group. These audios not only contain her introduction to Shamanism, but also interpretations of Buddhist scriptures. The researcher has also noticed that many group members in Group C, including the group owner and managers, often use concepts from other belief systems such as "spirit guide" and "tutelary deity " when explaining issues related to Shamanism. These are all concrete manifestations of the group's composite belief system.

Online religions have an unprecedentedly open communication platform that traditional religions do not have (Wang\&Wang, 2016). For any religion, inclusiveness will always benefit the spread and development more than exclusiveness, especially in the pluralistic and open internet. Depending on the high 
inclusiveness, the folk religion incorporated information from other religions in the process of cyberization. Although the belief system changed a lot, the religion as a whole stood firm in internet space. In the online religious groups like Group C, it was not just followers of Shamanism in northern China who were active. Benefited from high inclusiveness, those who are interested in Shamanism in northern China but do not believe in it, or the followers of this religion who also have other religious belief could also take part in the religious discussion and practices in virtual communities. During this process, colliding of various belief systems is reshaping this community's belief system.

From the angle of religious leader, the shift of belief system from single type to composite type is somewhat conscious. Especially when this belief system colliding with the technology paradigm of internet, the role of religion leaders as the disseminators decide that they need to change consciously to fit in with the new situations of internet. The Shamanism in northern China is a good example. In the previous belief system of which, immortals were called Chumaxian (which is a kind of immortals, not a single one). Many mages performed rites as Chumaxians' disciples (agents of Chumaxian in human world, or be called Shaman). While about ten years ago, the concept of Chudaoxian appeared in this religion, becoming popular in recent few years. As another kind of agents of immortals in human world, Chudaoxians' disciples were much different from Chumaxians' disciples. Chudaoxians' disciples had the power of remote viewing and remote sensing, which allow them to perform rites through the internet. The interactive mode through internet conflicted with the traditional face to face rites in Shamanism in northern China, which undoubtedly promoted the change of its belief system. This conflict was mediated by incorporating Western supernatural concepts such as remote viewing and remote sensing into its belief system, which reflected the choice of offline religion to adapt to the internet technology consciously.

\section{Religious authority: Diffuseness and the continuation of authority}

Regarding the influence of religious cyberization on religious authority, some studies believe that cyberization will erode religious authority, while some scholars have suggested that religious authority still exists in the internet space. Fukamizu studied 2,007 Buddhist followers and religious experts in Japan. In his research, he found that in addition to traditional religious doctrines, the stories and experiences shared by some individuals or groups have also been widely spread and referenced in the internet space. The influence of the disseminators of these messages on the followers is gradually surpassing the existing authoritative doctrines. As a result, the followers have become suspicious and critical of the traditional religious authority, and the authority of Japanese Buddhist monks has been eroded (Fukamizu, 2007). Possamai and Turner respectively studied the traditional religion represented by Islam, the modern-paganism represented by witchcraft and the surreal religion such as Jedi religion. They argue that because of authority habitus, religious authority persists even in an unhierarchical Internet space where authority can be redefined or fragmented (Possamai \& Turner, 2012).

The two terms for distinguishing religious types, diffused and institutional religion, were proposed by Qingkun Yang in the book Religion in Chinese Society (Marsh \& Yang, 1962). Diffused religion refers to a religion with theology, etiquette, and organization that is closely integrated with the secular system and social order which are not sacred. The organization of this type of religion is 
often very loose, and the doctrine and ritual norms are integrated into many aspects of secular life (Sa, 2018). In China, most of the folk religions other than the five major religions recognized by the government show diffused characteristics, and some of the five major religions outside the official system also have similar characteristics.

In a large number of studies on the internet and online religion, decentralization is considered an important feature of the internet. Many studies on Chinese internet religion have pointed out the threat to traditional religious authority and religious structure caused by the decentralization of the internet. For traditional religious authority, knowledge monopoly is an important foundation for its existence. In an open, diversified, and more accessible internet space, they are undoubtedly facing the possibility of stepping down from the altar. However, re-centralization and multi-centralization are also the trends in the internet society, which provides new possibilities for the continuation or formation of online religious authority. Due to the existence of authority habitus in the real world, religious communities in the internet space are likely to form a situation where authorities are crowded and competing with each other (Possmai \& Turner, 2014). From the perspective of the entire internet space, re-centralization and multi-centralization seem to be the changing trend of religious authority. However, through the observation of Group C, the researcher believes that, different from institutional religions such as Christianity and Islam, religious authority of diffused religions still keeps a high degree of recognition in the Internet space. This phenomenon is not obvious in the entire internet space, but can be better displayed in religious groups with a small number of people and a certain degree of closedness.

As a folk religion, Shamanism does not have official institutions and clerics, nor does it have systematic and written religious doctrines and ritual norms, so it conforms to the characteristics of a diffused religion. These characteristics have maintained the authority of religious leader in Group C to a certain extent. The group members of Group $C$ call the owner of the group master. She has absolute authority in the group, while the group managers with whom she is in close contact have the second level of authority (group managers are mostly disciples of group owner in reality). This kind of authority includes knowledge authority and symbolic authority, these are, the right to interpret religion-related issues and the sanctity of the group owner herself as a shaman. Discussions on doctrines and answers to the confusion of believers often appear in Group C. When these discussions only involve general group members, there will often be some collisions of different views, and sometimes even turn into a quarrel. Once the group owner makes an explanation on the relevant issue, the discussion on this issue will come to an end, and almost no one would question or refute her explanation. On one occasion, a group member was not very respectful to the group owner in the process of performing a religious rite through live streaming. Soon it attracted a lot of reprimands from other group members, which also confirmed the authority effectiveness of group owner among the majority of group members.

The reason why the owner of Group C can still have a high degree of authority in the internet space is related to the characteristics of diffused religion. Institutional religions often have recognized religious scriptures and systematic doctrines. The dissemination of such information in the internet space has broken the traditional religious authority's monopoly on knowledge, thereby weakening their authority to a certain extent. But diffused religion has a different situation on this issue. Although the doctrines of diffused religions are diverse and of large 
amounts, they are not systematic, and there is no official religious institution to endorse them. Compared with institutional religions, believers can only get scattered information about diffused religions from various sources in the internet space, and this information is mixed with good and bad. The easy accessibility and openness of information in the Internet space are less helpful to them. Under this circumstance, the religious authority of diffused religion can still monopolize religious knowledge to a large extent in the internet space, and its authority can therefore be maintained. Of course, group owners and group managers are the maintainers of group order, with the power to admit and remove general group members. They can determine the presence or absence of general group members in the group, hence forming a deterrent to group members. Further research is needed to determine whether such authority is stronger or weaker than religious authority.

\section{Religious experience: The phenomenon of self-centeredness}

Religious experience is an indispensable basis for the existence of religious belief, and this is also true in the Internet space. With the tendency of contemporary religions to belittle creeds and doctrines (Clark et al., 2002), religious experience has become even more important in religious life. Previous studies have affirmed the possibility of the internet as a sacred space, and also focused on the phenomenon of the individualization of religious experience in online religion. Hutchings conducted case studies on three online churches, and concluded that believers can also be immersed in religious experience in virtual sacred spaces, and then questioned some early studies that believed that online religious experience could not replace worship in reality (Hutchings, 2007). Krueger's research reveals the individualization of online religious experience. He believes that individual believers use the power of the internet to bypass the man-made or non-human obstacles in traditional religions, so as to achieve an individualized spiritual life in the internet space (Krueger, 2004). Armfield and Holbert point out in their research the phenomenon that more and more believers break away from organized religious institutions in the context of the internet, and believe that although this phenomenon is a manifestation of secularization on the surface, it actually represents the revival of religion on the individual level (Armfield \& Holbert, 2003).

In the observation of Group $\mathrm{C}$, the researcher found that while the religious experience of online religion showed the above-mentioned trend of individualization, there also appeared many phenomena of self-centeredness. Individualization is the opposite of organization, which represents the tendency of believers to break away from religious organizations or communities in the Internet space. In contrast to individualization, self-centeredness is the opposite of egalitarianism, aiming to show that believers emphasize their own importance in religious experience. This phenomenon can be compared to the Christians' belief that they have received more attention from God than others, and that they are bound to enter heaven eventually. In the internet space, many believers have developed a self-centeredness, or self-perception of themselves as having an important divine identity and mission.

In the religious system of Shamanism, every believer is inextricably linked with different immortals. These immortals can influence the fortune of believers. Their magic power can also reflect the abilities of believers, and some immortals will also give believers an important sacred mission. Among the offline religious traditions, Shamanism has 
strong regional characteristics. Believers' understanding of this religion basically comes from the introduction of people around them, and there are only a few authoritative shamans in each region. In this case, the identity of the immortals linked to believers was mostly identified and pointed out by the local shaman, and there was little room for self-interpretation of the doctrines and witnesses. However, the openness and pluralism of the internet provide believers with more possibilities. In addition to local or online shamans, they can also choose to discover their immortals with the help of other believers or through their own exploration.

Many believers in Group C believe that they are favored by the powerful immortal and shoulder the important mission of saving the world and helping the people. They have experienced a lot of witnesses in their lives, and tried to prove their important sacred identity through these witnesses in the group. Most of these believers are young people in their 20s and 30s. Compared with middle-aged and elderly believers, they use the Internet more frequently and skillfully. Also, their belief systems are more pluralistic. The researcher had a face-to-face interview with such a believer in Group C. He believes that he was a prince from another planet in previous lives, and he was one of the disciples of Buddha. He also has a very important mission in this life. He perceives that a lot of signs are happening around him, such as his ability to summon the spirit from another world to paint, to talk to Buddha. And these signs appeared to guide him to recognize his identity and mission. In his own words, he was at the center of the whirlpool. In general, in his daily religious experience, he gradually formed a recognition that he has important sacred identity and missions, and is the central figure of a major event.

This phenomenon of self-centered religious experience is not universal, but mostly appears among younger believers, and its formation is related to the background and experience of believers themselves. However, the pluralistic and free belief space provided by the internet for believers is an important basis for this phenomenon. First of all, believers can access information from different religious beliefs in the internet space, so that they can break away from the belief system and thinking framework of a certain religion, and form a new understanding of their original beliefs, or construct a new belief system. In addition, believers have a high degree of freedom on the Internet, and the answers to questions about what is witness and how to interpret doctrines are largely in their hands. They construct personalized belief systems based on various religious information derived from the internet, and then obtain self-centered religious experiences through their own interpretation of witnesses. This freedom does not conflict with the religious authority that still exists in the internet space. It's not that this part of believers does not recognize the authority of religious leaders, but in many cases no longer need to confirm their religious thoughts through religious leaders. They can find many likeminded believers with similar ideas as long as they raise their arms on the internet. These believers take full advantage of the diversity and freedom of the internet, embedding their self-centered religious witnesses into their own life experiences, thereby achieving a satisfying religious experience.

\section{Conclusion}

In the above discussion, this article explored the influence of religious cyberization on traditional belief system, religious authority and religious experience. In terms of belief system, higher inclusiveness is conducive to the spread and development of folk religions in the internet space. 
Therefore, the belief system of individual believers or groups have a tendency to shift from a single type to a composite type. From the perspective of religious disseminators, this transformation is conscious in many cases. In terms of religious authority, religious leaders of diffused religions still monopolize religious knowledge to a large extent in the Internet space, and their authority can continue in the virtual sacred space. In terms of religious experience, the researcher has observed the phenomenon of self-centeredness of religious experience in online religion, and the pluralism and freedom of the Internet are the bases of this phenomenon. The emergence and development of internet technology has promoted many social changes. For religions, the internet can be used both as a new belief space and as an instrumental force, presenting both opportunities and challenges. In the case of China's folk religions, their inherent inclusiveness and diffuseness seem to make them more adapted to the new territory of the internet than many officially recognized religions. These situations where religions are closely integrated with people's secular lives may be playing out again in the Internet space.

This study mainly has the following limitations. Firstly, limited by the research methods and data collected, this study only discusses the influence of cyberization on belief system, religious authority and religious experience, but does not involve more aspects of religion. Secondly, since this study adopted a case study method, the extent to which the above conclusions are universal remains to be further tested.

\section{Declaration of Ownership}

This article is my original work.

\section{Conflict of Interest}

There is no conflict of interest to declare in this article.

\section{Ethical Clearance}

This study was approved by the institution.

\section{References}

Armfield, G. G., \& Holbert, R. L. (2003). The relationship between religiosity and internet use. Journal of Media and Religion, 2(3), 129-144. https://doi.org/10.1207/ s15328415jmr0203_01

Brasher, B. (2001). Give me that online religion. Choice Reviews Online, 39(02). https://doi.org/10.5860/choice.39-0876

Clark, L. S., Hadden, J. K., \& Cowan, D. E. (2002). Religion on the internet: Research prospects and promises. Sociology of Religion, 63(4), 540-541. https://doi. org/10.2307/3712307

Cobb, J. (1998). Cybergrace: The search for God in the digital world. Crown Publishers.

Fukamizu, R. K. (2007). Internet use among religious followers: Religious postmodernism in Japanese Buddhism. Journal of Computer-Mediated Communication, 12(3), 977-998. https:// doi.org/10.1111/j.1083-6101.2007.00359.x

Helland, C. (2000). Online religion/religion online and virtual communitas. religion on the internet: Research prospects and promises, ed. Jeffrey K. Hadden, Dougles E. Cowan, JAI Press, 8, 205223. Retrieved from http://books.google. com/books?id=iS80IHp0cDwC\&pg=PA 105\&lpg=PA105\&dq=Online-religion/ religion-online+and+virtual+communita s\&source=bl\&ots $=$ gwOoakhqVV\&sig $=$ vZdggLUGLfNebPjfzacEuvReLA\&hl $=$ en $\&$ ei $=11$ y 8 ToPTOqfO $2 \mathrm{gWDhp} 2$ aBQ\&sa=X\&oi=book_result\&ct $=$ result \&resnum $=6 \&$ ved $=$ 
Huang, L. P. (2018). The O2O model for Japanese religious groups๑A case study of the Konkokyo Momoyama Church. The World Religious Cultures (01), 8896. Retrieved from https://kns.cnki.net/ kcms/detail/detail. aspx?FileName= RELI201801017\&DbName= CJFQ2018

Hutchings, T. (2007). Creating church online: A case-study approach to religious experience. Studies in World Christianity, 13(3), 243-260. https://doi.org/10.3366/ swc.2007.13.3.243

Krueger, O. (2004). The internet as distributor and mirror of religious and ritual knowledge. Asian Journal of Social Science, 32(2), 183-197. https://doi. org/10.1163/1568531041705077

Liang, W. G. (2020). The internet experience of believers and the changing governance of authority: A review of "internet + religion" research at home and abroad. Studies in World Religions, (03),183-188. Retrieved from https://kns.cnki.net/ $\mathrm{kcms} /$ detail/ detail.aspx?FileName= WORL202003021 $\&$ DbName $=$ CJFQ2020

Li, C. M., \& Gu, F. Y. (2018). Characteristics, risks and comprehensive management of online religion. Inner Mongolia Theory Research of United Front, (5), 4954. Retrieved from https://kns.cnki. net/kcms/detail/detail.aspx?FileName $=$ LMTZ201805014 \&DbName=CJFQ2018

Li, M. (2011). The religion's internet communication and the believer's group identification. Journal of Hebei Normal University of Science \& Technology, 10(2), 32-36. Retrived from https://kns.cnki. net $/ \mathrm{kcms} /$ detail/detail.aspx? FileName= HZYS201102008\& DbName=CJFQ2011

Ma, J. (2016). Cybermatics for cyberization towards cyber-enabled hyper worlds. 2016 4th IEEE International Conference on Mobile Cloud Computing, Services, and Engineering (MobileCloud). https://doi. org/10.1109/mobilecloud.2016.17
Ma, N. (2020). Research on the current situation and management strategies of internet religious activities in China. Science and Atheism, (01), 29-35. Retrieved from https://kns.cnki.net/ kcms/detail/detail.aspx? FileName= KXWS202001007\&DbName $=$ CJFQ2020

Marsh, R. M., \& Yang, C. K. (1962). Religion in Chinese society: A study of contemporary social functions of religion and some of their historical factors. American Sociological Review, 27(3), 439. https://doi. org/10.2307/2089842

O'Leary, S. D. (1996). Cyberspace as sacred space: Communicating religion on computer networks. Journal of the American Academy of Religion, LXIV(4), 781-808. https://doi.org/10.1093/jaarel/ lxiv.4.781

Possamai, A., \& Turner, B. S. (2012). Authority and liquid religion in cyberspace: The new territories of religious communication. International Social Science Journal, 63(209-210), 197-206. https://doi.org/10.1111/issj.12021

Sa, J.X.(2018). An analysis of the "diffuseness" of religion in China. Jing Chu Academic Journal, 2018, (17), 122-124. Retrieved from https://kns.cnki.net/kcms/detail/detail. aspx? FileName $=$ HGZK201806001033\& DbName=CPFD2018

Shi, L. (2016). Research on online religion, online society and social governance: A case study of S City. The World Religious Cultures, (5), 18-23. Retrieved from https://kns.cnki.net/ $\mathrm{kcms} /$ detail/detail.asp $\mathrm{x}$ ?FileName $=$ RELI201605005\&DbName $=$ CJFQ2016

Shi, L. (2018). Reflection on the issue of online religion in China and its overall governance. Information Security and Communications Privacy, (3), 20-22. Retrieved from https:// kns.cnki.net/kcms/detail/ detail. aspx? FileName=TXBM201803006\& DbName $=$ CJFQ2018 
Shi, L., \& Lu, J. H. (2016). The rise of online religion and its social governance. China Ethnic News, 006. Retrieved from https:// wenku.baidu.com/view/1683d125b94cf7 ec4afe04a1b0717fd5370cb2c3? fr=xueshu

Tang, M. H. (2006). Exploring the social mechanism of the rise of online religion. Religious Studies, (4), 216-220. Retrieved from https://kns.cnki.net/kcms/detail/ detail.aspx?FileName=ZJYJ 200604043\& DbName $=$ CJFQ2006

Tang, M. H. (2008). Influence of network religion on Christians: A case study of religious life of online Christians in Changsha. Religious Studies, (2), 112116. Retrieved from https://kns.cnki. net $/ \mathrm{kcms} /$ detail/detail.aspx? FileName= ZJYJ200802022\& DbName= CJFQ2008

Tan, J. H. (2019). Research on the new form of religious activities on mobile internet: Taking the social interaction of Buddhist virtual community as an example. (Master Thesis, Wuhan University). Retrieved from https://kns.cnki.net/KCMS/detail/detail. aspx?dbname $=$ CMFD201902\&filename $=$ 1019903142.nh

Wang, H. \& Wang, Y. (2016). An analysis of the online religion: Taking Gansu Province as the research object. Journal of Tianshui Normal University, (02), 60-64. Retrieved from https://kns.cnki.net/kcms/detail/ detail. aspx?FileName=TSSY201602017\& DbName $=$ CJFQ2016

Wang, N. N. (2016). Research on the current development situation and countermeasures of online religion in China. Journal of the Central Institute of Socialism, 201(3), 63-66. Retrieved from https://kns.cnki.net/kcms/detail/detail. aspx?FileName $=\quad$ ZYSH201603014\& DbName $=$ CJFQ2016

Xing, G.Z.(2016).AStudy on collegestudents' internet religion from the perspective of postmodernism. Studies on Marxism, (11), 132-140. Retrieved from https://kns.cnki. net $/ \mathrm{kcms} /$ detail $/$ detail.aspx?FileName= STUD201611015\&DbName= CJFQ2016

Xu, S., \& Campbell, H. A. (2018). Surveying digital religion in China: Characteristics of religion on the internet in Mainland China. The Communication Review, 21(4), 253-276. https://doi.org/10.1080/1071442 1.2018.1535729

Yang, J. W. (2018). Connotation analysis of "internet religion" and its significance to internet governance. Information Security and Communications Privacy, (3), 13-16. Retrieved from https:// kns.cnki.net/kcms/detail/detail. aspx? FileName=TXBM201803004\& DbName $=$ CJFQ2018

Zhang, Y., Ma, X.C., \& Zhang, Z.H. (2018). The communication and administration of online religious activities in China: Taking ethnic city $x$ in Western China as an case study. Qinghai Journal of Ethnology, 29(4), 212-217. Retrieved from https://kns.cnki. net/kcms/detail/detail.aspx?FileName= QHMJ201804033\&DbName= CJFQ2018

Zhang, Z. (2018). Belief conversion in embedded networks: Ethnography of WeChat group based on "respecting the lord". (Master Thesis, Liaoning University). Retrieved from https://kns.cnki.net/ KCMS/detail/detail.aspx?dbname= CMFD201901\&filename $=1018109452 . \mathrm{nh}$ 